\title{
A Novel Immuno-RNase Based on Engineered RNase A Variants for Targeted Cancer Therapy
}

Masoume Vakili Azghandi ( $\square$ m.vakili2009@gmail.com )

Ferdowsi University of Mashhad https://orcid.org/0000-0003-1169-9147

Mohammadreza Nassiri

Ferdowsi University of Mashhad

Veysel Kayser

The University of Sydney School of Medicine

Ali Javadmanesh

Ferdowsi University of Mashhad

Shahrokh Ghovvati

University of Guilan

Keywords:

Posted Date: June 22nd, 2020

DOI: https://doi.org/10.21203/rs.3.rs-36546/v1

License: (1) This work is licensed under a Creative Commons Attribution 4.0 International License.

Read Full License 


\section{Abstract}

The authors have requested that this preprint be removed from Research Square. 